A N N A L E S

UNIVERSITATIS MARIAE CURIE-SKŁODOWSKA

LUBLIN - POLONIA

VOL. LXIII, 2

SECTIO G

2016

Uniwersytet Marii Curie-Skłodowskiej w Lublinie

bartosz.lizewski@poczta.umcs.lublin.pl

\title{
BARTOSZ LIŻEWSKI
}

\section{Klauzule generalne i ich funkcje w Europejskiej Konwencji Praw Człowieka}

General Clauses and their Functions in the European Convention of Human Rights

\section{AKSJOLOGIA W SYSTEMIE PRAWA KRAJOWEGO}

Kiedy porusza się zagadnienie wymiaru aksjologicznego systemu prawa krajowego, to tradycyjnie wskazuje się na dwa składniki tej aksjologii. Pierwszym z nich jest aksjologia prawna, która jest wyrażana za pośrednictwem zasad prawa, a drugim - aksjologia pozaprawna ujmowana w postaci klauzul generalnych. U jej podstaw leżą wartości funkcjonujące w życiu społecznym, które są na tyle ważne i uniwersalne zarazem, że okazują się konieczne dla dokonywania odwołania się do nich w treści prawa na potrzeby jego stosowania. Jak pisze L. Leszczyński:

Tym, co odróżnia zasady prawa od klauzul generalnych w kontekście ustalania ich treści, jest to, że „poszukiwanie” treści zasady odbywa się w ramach systemu prawa, a więc w ramach wartości, które prawodawca „wyraźniej” określa i chroni przez system normatywny, podczas gdy przy klauzuli poszukiwanie odbywa się poza systemem wartości określonych prawnie.

Przyjmując powyższą dywersyfikację na zasady prawa i klauzule generalne, dokonuję z pełną świadomością pewnego uproszczenia, ponieważ obie konstrukcje są ontologicznie obciążone cechą wieloznaczności. Z uwagi na to, że teza ta jest w pełni ugruntowana w literaturze i objęta szeroką naukową refleksją ${ }^{2}$, nie

\footnotetext{
1 L. Leszczyński, Klauzule generalne w stosowaniu prawa, Lublin 1986, s. 37.

2 Na wieloznaczność pojęcia „zasady prawa” powołują się np. S. Tkacz, O zintegrowanej koncepcji zasad prawa w polskim prawoznawstwie (od dogmatyki do teorii), Torun 2014, s. 131-136;
} 
jest celem niniejszego artykułu wyjaśnianie tych wieloznaczności. Na potrzeby rozważań o klauzulach generalnych w Europejskiej Konwencji Praw Człowieka pragnę w pierwszej kolejności wykazać zasadnicze różnice w sposobie wyrażania aksjologii $\mathrm{w}$ systemach prawa wewnętrznego i międzynarodowego. Te dysproporcje $\mathrm{w}$ sposób zasadniczy wpływają na istotę obu tych konstrukcji w prawie międzynarodowym.

W systemie prawnym państwa zestawienie zasad prawa i klauzul generalnych ma na celu zwrócenie uwagi na różne źródła aksjologii wykorzystywanej zarówno w budowaniu systemu prawa, jak i w procesach stosowania prawa. Trudno zresztą współcześnie wyobrazić sobie procesy decyzyjne stosowania prawa bez udziału w nich obu tych typów aksjologii, chociaż walor większej doniosłości przypisuje się bez wątpienia aksjologii prawnej. Dokonując pewnego uogólnienia, należy przyjąć, że zasady prawa to normy prawne, które nakazują (zakazują) realizowanie określonej wartości ${ }^{3}$. Tę ogólną definicję należy jednak dookreślić, ponieważ zasady prawne są wyrażane w normach o najwyższej mocy prawnej, tj. normach konstytucyjnych oraz ustawowych, przez co mają za zadanie chronić „wartości usytuowane na szczycie aksjologicznej hierarchii prawodawcy”. W związku z powyższym zasady prawa są nie tylko uwikłane aksjologicznie, ale też kształtują sferę wartości, na których prawo się opiera, będąc wyrazem preferencji ustawodawcy stanowiącego akt normatywny. Wyrażają więc wartości podstawowe dla całego systemu prawnego lub co najmniej jednej gałęzi prawa czy działu prawa ${ }^{5}$. Można powiedzieć, że zasady prawa są aksjologicznym kręgosłupem całego sytemu prawa, zarówno na poziomie ogólnosystemowym, jak i na poziomie jego poszczególnych gałęzi. Mają one kluczowe znaczenie w procesach tworzenia prawa, ponieważ determinują ,treść” norm zwykłych, wyznaczających wzorce zachowania dla adresatów, w procesach badania konstytucyjności prawa, gdyż stanowią punkt odniesienia dla jej dokonywania, a w procesach stosowania prawa są wykorzystywane między innymi jako argument aksjologiczno-systemowy wykładni.

Pojęcie „klauzula generalna” jest terminem języka praktyki i doktryny prawniczej ${ }^{6}$. Stanowi autonomiczną konstrukcję normatywną, która jest powołana do realizowania innych funkcji niż zasady prawa. Pod pojęciem tym należy rozumieć fragment przepisu, któremu można przypisać jako celowy zabieg pra-

G. Maroń, Zasady prawa. Pojmowanie i typologie a rola $w$ wykladni prawa i orzecznictwie konstytucyjnym, Poznań 2011, s. 11, 13-16; S. Wronkowska, M. Zieliński, Z. Ziembiński, Zasady prawa. Zagadnienia podstawowe, Warszawa 1974.

3 M. Kordela, Zasady prawa. Studium teoretycznoprawne, Poznań 2012, s. 102.

4 L. Leszczyński, G. Maroń, Pojęcie i treść zasad prawa oraz generalnych klauzul odsyłajacych. Uwagi porównawcze, „Annales UMCS. Sectio G” 2013, Vol. 40, nr 1, s. 81.

5 Ibidem.

6 Ibidem, s. 82. 
wodawcy niedookreślony znaczeniowo charakter, którego istotą jest odesłanie do wartości pozaprawnych. Słusznie zatem pisze G. Maroń, że klauzule generalne cechuje semantyczna nieprecyzyjność i pozaprawna natura odesłania ${ }^{7}$. Ustawodawca za pośrednictwem klauzuli generalnej kierunkuje organ stosujący prawo na wartości gospodarcze, moralne, obyczajowe, polityczne czy religijne, które służą ocenie korzystania przez adresata z praw podmiotowych. Ocena ta jest dokonywana przez organ stosujący prawo, który ostatecznie ustala treść klauzuli generalnej sytuacyjnie, tj. w odniesieniu do ustalonego stanu faktycznego $\mathrm{w}$ realizowanym procesie decyzyjnym. Za pośrednictwem tej instytucji ustawodawca realizuje dwa ściśle powiązane ze sobą cele. Po pierwsze, włącza na potrzeby prawa do systemu prawa wartości, które są zasadniczo od prawa niezależne i w sposób autonomiczny istnieją w stosunkach międzyludzkich. W ten sposób za pośrednictwem zapożyczenia wartości z systemu norm społecznych zasadniczo zostaje rozszerzona perspektywa aksjologiczna prawa. Dzięki temu zabiegowi, po drugie, ustawodawca w sposób świadomy kreuje luz decyzyjny organów stosujących prawo, które za pośrednictwem aksjologii pozaprawnej mogą i powinny łagodzić instrumentalny charakter prawa.

Odesłania pozaprawne, kreowane przez klauzule generalne, podobnie jak w przypadku zasad prawa, mogą być ustanowione na potrzeby jednej gałęzi prawa albo w wymiarze ogólnosystemowym. Bez wątpienia najbardziej uniwersalną klauzulą generalną w przekroju gałęzi systemu prawa polskiego są zasady współżycia społecznego. Na gruncie prawa cywilnego i prawa pracy ujęte są systemowo $\mathrm{w}$ powiązaniu $\mathrm{z}$ klauzulą społeczno-gospodarczego przeznaczenia prawa. Wyrażające je przepisy art. 5 k.c. i art. 8 k.p. uzyskały nawet analogiczne brzmienie ${ }^{8}$. W kodeksowej regulacji prawa pracy odwołanie do klauzuli współżycia społecznego znajdziemy także w art. $100 \S 2$ pkt 6 , w którym ustawodawca, normując obowiązki pracownika, nakazuje mu także przestrzegać w zakładzie pracy zasad współżycia społecznego. W prawie karnym również znajdziemy odwołanie do zasad współżycia społecznego. W regulacji proceduralnej art. $2 \S 1$ k.p.k. ustawodawca, określając założenia ukształtowania postępowania karnego, wskazał także (pkt 2), aby postępowanie to było przeprowadzane w oparciu o zasady współżycia społecznego. W wielu przypadkach specyfika klauzuli materializuje się wyłącznie w zakresie specyfiki gałęzi, w której jest formułowana. Taki charakter w prawie rodzinnym ma klauzula dobra dziecka, która jest ujęta np. w art. $56 \S 1$ k.r.o. jako negatywna

7 G. Maroń, op. cit., s. 90.

8 Art. 5 kodeksu cywilnego i art. 8 kodeksu pracy stanowią: „Nie można czynić ze swojego prawa użytku, który byłby sprzeczny ze społeczno-gospodarczym przeznaczeniem tego prawa lub z zasadami współżycia społecznego. Takie działanie lub zaniechanie uprawnionego nie jest uważane za wykonywanie prawa i nie korzysta z ochrony". 
przesłanka rozwodowa ${ }^{9}$, czy w prawie handlowym jako klauzula słusznych interesów konsumenta, sformułowana np. w art. 17 ustawy o swobodzie działalności gospodarczej ${ }^{10}$.

\section{AKSJOLOGIA W SYSTEMIE NORM PRAWA MIĘDZYNARODOWEGO I MIĘDZYNARODOWEGO PRAWA PRAW CZŁOWIEKA}

Porównując specyfikę systemu prawa krajowego z systemem prawa międzynarodowego, skupiając się wyłącznie na wymiarze aksjologicznym, należy postawić tezę, że prawo międzynarodowe jest bardziej otwarte aksjologicznie niż prawo krajowe ${ }^{11}$. Jednocześnie przejście z poziomu prawa międzynarodowego ogólnego na poziom prawa międzynarodowego praw człowieka jeszcze bardziej tę otwartość pogłębia. Z punktu widzenia siły konstrukcji, które są normatywnym nośnikiem aksjologii w prawie międzynarodowym, szczególne znaczenie mają ogólne zasady prawa uznane przez narody cywilizowane, które w języku prawnym i prawniczym są też powszechnie nazywane uznanymi zasadami prawa międzynarodowego, także wobec argumentu podkreślającego archaiczność nazwy sformułowanej w art. 38 ust. 1 pkt c Statutu Międzynarodowego Trybunału Sprawiedliwości ${ }^{12}$. Szczególne ich znaczenie w prawie międzynarodowym wynika z połączenia kilku ich właściwości.

Zasady prawa międzynarodowego w perspektywie całej przestrzeni międzynarodowej mają charakter niekwestionowany. Są uznane przez wszystkie państwowe porządki prawne, niezależnie od zróżnicowania kulturowego, politycznego, społecznego czy ekonomicznego. Zyskują przez to wymiar uniwersalny i w tym sensie są kategorią wspólną dla porządków prawa krajowego i prawa międzynarodowego. Są aksjologicznym spoiwem przestrzeni międzynarodowej, w której niejednokrotnie różne grupy państw wiążą się w tym samym zakresie przedmiotowym prawem o różnej treści. Jest to oczywiście zrozumiałe, ponieważ każde państwo chce się wiązać prawem, które będzie zgodne z jego interesami. Musi to jednak czynić w zgodzie z aksjologicznymi regułami funkcjonowania systemu.

$\mathrm{W}$ ujęciu fontes iuris zasady prawa międzynarodowego są kategorią interźródłową. Aktualnie nie tylko zalicza się je do samodzielnych źródeł prawa

9 Art. $56 \S 1$ kodeksu rodzinnego i opiekuńczego stanowi: „Mimo zupełnego i trwałego rozkładu pożycia rozwód nie jest dopuszczalny, jeżeli wskutek niego miałoby ucierpieć dobro wspólnych małoletnich dzieci małżonków".

10 Art. 17 ustawy o swobodzie działalności gospodarczej stanowi: „Przedsiębiorca wykonuje działalność gospodarczą na zasadach uczciwej konkurencji i poszanowania dobrych obyczajów oraz słusznych interesów konsumentów".

11 B. Liżewski, Operacjonalizacja ochrony praw człowieka w porządku Europejskiej Konwencji Praw Człowieka (studium teoretycznoprawne), Lublin 2015, s. 296.

12 A. Łazowski, A. Zawidzka, Prawo międzynarodowe publiczne, wyd. 2, Warszawa 2003, s. 46. 
międzynarodowego, ale niezależnie od tego są one również włączane do umów międzynarodowych i wynikają ze zwyczaju. Pomimo tego, że należy uznać ogólne zasady prawa międzynarodowego za samodzielne źródło prawa, jednocześnie podkreśla się, że mają one charakter pomocniczych źródeł prawa i służą rozstrzyganiu wątpliwości przy stosowaniu postanowień traktatowych i zwyczajowego prawa międzynarodowego ${ }^{13}$.

Z kolei z punktu widzenia treściowego zasady prawa międzynarodowego nie są kategorią jednolitą. Nie chodzi przy tym bynajmniej o spory, czy zaliczyć do nich bezwzględnie wszystkie zasady ${ }^{14}$ czy zasady, które są wspólne dla systemów prawnych wszystkich państw ${ }^{15}$, czy zasady należące do systemów prawnych prawa wewnętrznego i międzynarodowego ${ }^{16}$. Skupiając się na treści zasad, należy poruszyć zagadnienie ich pojemności aksjologicznej. Wartości, których nośnikiem są ogólne zasady prawa międzynarodowego, początkowo obejmowały wyłącznie sferę prawną. $Z$ czasem do ich grupy zaczęto zaliczać słuszność dzięki powoływaniu się na tę wartość przez międzynarodowe trybunały. Za sprawą tradycji rzymskiej, w ujęciu której słuszność to pewien zbiór zasad wykorzystywanych w procesach decyzyjnych ${ }^{17}$, słuszność jako wartość zewnętrzna wobec prawa międzynarodowego stała się częścią składową corpus iuris gentium. W ten sposób zaliczenie słuszności, będącej nośnikiem wartości pozaprawnych, do zasad prawa międzynarodowego zwiększyło aksjologiczną pojemność i zarazem uniwersalność tego źródła prawa międzynarodowego.

Pojemność aksjologiczna ogólnych zasad prawa międzynarodowego determinuje rozbudowane funkcje, jakie pełnią one w całym systemie prawa międzynarodowego. Wypełniają one luki prawne, są wykorzystywane w procesie interpretacji, za ich pośrednictwem dokonuje się korekty źródeł prawa pisanego, a także mogą być inspiracją dla kreowania postanowień umów międzyna-

13 J.G. Lammers, General Principles of Law Recognized by Civilized Nations, [w:] Essays on the Development of the International Legal Order. In Memory of Haro F. van Panhuys, eds. F. Kalsharen, P.J. Kuyper, J.G. Lammers, Sithoff 1980, s. 74.

${ }_{14} \mathrm{Na}$ takim stanowisku stoją W. Czapliński i A. Wyrozumska. Autorzy ci uważają, że do zasad prawa międzynarodowego zalicza się zarówno te zasady, które wywodzą się z prawa krajowego, jak i międzynarodowego, włącznie z ogólnie przyjętymi regułami rozumowań prawniczych. Zob. W. Czapliński, A. Wyrozumska, Prawo międzynarodowe publiczne. Zagadnienia systemowe, Warszawa 1999, s. 90.

$15 \mathrm{Na}$ takim stanowisku stoi J. Gilas w pracy Prawo międzynarodowe (wyd. 2 popr. i zm., Toruń 1999, s. 54).

16 Takie stanowisko prezentuje W. Góralczyk w pracy Prawo międzynarodowe publiczne w zarysie (wyd. 8 zm. i popr. przez S. Sawickiego, Warszawa 2002, s. 67).

17 J. Połatyńska, Pozycja stuszności w prawie międzynarodowym, [w:] Prawo międzynarodowe wobec wyzwań wspótczesnego świata, red. E. Dynia, Rzeszów 2009, s. 3. 
rodowych ${ }^{18}$. Szczególne znaczenie mają w procesie stosowania prawa międzynarodowego, ponieważ wprowadzone zostały właśnie dla uelastycznienia tego procesu. Podkreśla się również ich funkcje w kreowaniu normatywnej podstawy decyzji, dzięki czemu zasady wykluczają powstanie sytuacji określanej mianem non liquet ${ }^{19}$. W opinii M.N. Shawa zasady ogólne wprowadzono dlatego, że w prawie międzynarodowym nie ma metody pozwalającej na przyjmowanie norm regulujących nowe sytuacje ${ }^{20}$.

Aksjologiczna pojemność ogólnych zasad prawa międzynarodowego, a przede wszystkim wyrażanie za pomocą tego fontes iuris wartości pozaprawnych, jest prawdopodobnie głównym powodem tego, że klauzule generalne w prawie międzynarodowym nie stały się tak powszechną konstrukcją normatywną, jak w kontynentalnych krajowych porządkach prawnych. To, że prawo międzynarodowe poradziło sobie ,inaczej” z zagadnieniem aksjologii pozaprawnej nie oznacza, że całkowicie zrezygnowało z instytucji klauzul generalnych. Traktaty prawa międzynarodowego praw człowieka, a w jego ramach EKPC, są tego dostatecznym przykładem. Trzeba jednak podkreślić, że traktaty praw człowieka ukształtowały instytucje klauzul generalnych w sposób autonomiczny i niezależny od prawa krajowego. Ich wspólnym mianownikiem pozostają wartości pozaprawne. Podmioty decyzyjne, które mają się do tych wartości odwoływać, oraz sposób ich wykorzystania w procesach decyzyjnych nie są już takie same. Instytucja klauzul generalnych w prawie międzynarodowym praw człowieka służy przede wszystkim umożliwieniu ograniczenia praw człowieka w porządkach prawa krajowego. Należy też zauważyć, że konstrukcja klauzul przyjęta na gruncie EKPC stwarza również możliwość rozszerzenia zakresu prawa chronionego w prawie krajowym ze względu na pozaprawne wartości.

\section{FORMUŁA PODSTAWOWA KLAUZUL LIMITACYJNYCH W EUROPEJSKIEJ KONWENCJI PRAW CZŁOWIEKA}

Pod pojęciem klauzul limitacyjnych należy rozumieć zawartą w przepisach EKPC konstrukcję umożliwiającą ograniczanie praw i wolności jednostek, dlatego dość często klauzule te nazywa się klauzulami ograniczającymi. Źródłem konstrukcji limitacji jest co najmniej kilka przepisów EKPC. Należy podkreślić, że sama konstrukcja jest zróżnicowana i obejmuje kilka formuł, które przewidują różny zakres ograniczania praw i wolności człowieka. Nie zawsze limitacja musi

18 A. Wentkowska, Zasady wspólne dla państw członkowskich - u źródet niepisanego ius commune Europaeum, [w:] Zasady ogólne prawa wspólnotowego, red. C. Mik, Torun 2007, s. 26.

19 Encyklopedia zagadnień międzynarodowych, red. E. Cała-Wacinkiewicz, R. Podgórzańska, D. Wacinkiewicz, Warszawa 2011, s. 220.

20 M.N. Shaw, Prawo międzynarodowe, przeł. J.J. Gojło [et al.], Warszawa 2011, s. 90. 
oznaczać ograniczenie praw, czasami może prowadzić nawet do rozszerzenia zakresu prawa gwarantowanego Konwencją. Chociaż w literaturze przedmiotu jest dostrzegane zróżnicowanie tej konstrukcji, to jednak dość często kategoria przepisów wyrażająca konstrukcje klauzul limitacyjnych jest charakteryzowana dość jednolicie ${ }^{21}$. W moim przekonaniu konstrukcje te należy rozróżniać, tym bardziej że prawne możliwości państw co do określania zakresu praw chronionych w swoich porządkach prawnych, wynikające z tych różnych formuł, nie są takie same. Oznacza to, że w przypadku jednych praw zakres ingerencji w prawo może być większy, podczas gdy uprawnienie do ograniczania innych praw może być mniejsze. Z tego powodu należy wyeksponować formułę podstawową klauzuli limitacyjnej w EKPC oraz poddać analizie pozostałe konstrukcje umożliwiające ograniczanie praw i wolności człowieka. Określenie „formuła podstawowa” jest umowne - rozumiem pod nim rozwiązania przyjęte w przepisach wolnościowych EKPC, art. 8 (prawo do poszanowania życia prywatnego i rodzinnego), art. 9 (wolność myśli, sumienia i wyznania), art. 10 (wolność wyrażania opinii), art. 11 (wolność zgromadzania się i stowarzyszania się), a dokładniej - w ustępach drugich tych regulacji, oraz analogiczną klauzulę sformułowaną w ust. 3 art. 2 protokołu dodatkowego $\mathrm{nr} 4$ (prawo do swobodnego poruszania się).

Budowa klauzul ograniczających zawarta w powołanych wyżej przepisach opiera się na powiązaniu trzech elementów ${ }^{22}$. Pierwszym z nich jest adresat możliwości dokonania ograniczenia praw, drugim - szacunkowe wskazanie na konieczność dokonania takiej ingerencji, a trzecim - oparte w dużej mierze na wartościach pozaprawnych powody, ze względu na które ingerencja taka jest dokonywana. Konstrukcja tych przepisów jest bardzo podobna, ale nie tożsama, zarówno gramatycznie, jak i treściowo. Zmienia się postać ujęcia gramatycznego ograniczenia. Negatywne sformułowanie limitacji zastosowano w przypadku ust. 2 art. $8^{23}$ i art. $11^{24}$ oraz w art. 2 ust. 3 protokołu dodatkowego $\mathrm{nr} 4^{25}$. Z kolei w ustępach

21 Tezę taką stawia B. Latos, zwracając uwagę na różne nazewnictwo, tj. „klauzule limitacyjne”, ,warunki ograniczające”, „sankcjonowane ograniczenia”, a nawet „derogacja”. Zob. B. Latos, Klauzula derogacyjna i limitacyjna w Europejskiej Konwencji Praw Człowieka i Podstawowych Wolności, Warszawa 2008, s. 151.

22 Jako przykład można przytoczyć treść art. 8 ust. 2 EKPC: „Niedopuszczalna jest ingerencja władzy publicznej w korzystanie $\mathrm{z}$ tego prawa, $\mathrm{z}$ wyjątkiem przypadków przewidzianych przez ustawę i koniecznych w demokratycznym społeczeństwie z uwagi na bezpieczeństwo państwowe, bezpieczeństwo publiczne lub dobrobyt gospodarczy kraju, ochronę porządku i zapobieganie przestępstwom, ochronę zdrowia i moralności lub ochronę praw i wolności innych osób".

23 „Niedopuszczalna jest ingerencja władzy publicznej w korzystanie $\mathrm{z}$ tego prawa $\mathrm{z}$ wyjątkiem przypadków [...]”.

24 „Wykonywanie tych praw nie może podlegać innym ograniczeniom niż te, które [...]”.

25 „Korzystanie z tych praw nie może podlegać innym ograniczeniom niż te, które [...]”. 
drugich art. $9^{26} \mathrm{i}$ art. $10^{27}$ oparto się na formule pozytywnej. Niekiedy inaczej ujęte są też powody czy - inaczej mówiąc - przesłanki uzasadniające wprowadzanie ograniczeń. Nie wpływa to jednak na sens i istotę konstrukcji. Jednolitość formuły jest na tyle wystarczająca, „by możliwe było stosowanie jednakowej metodologii wykładni wszystkich czterech przepisów" ${ }^{28}$. Oczywiście analogiczna teza dotyczy powoływanej regulacji z protokołu dodatkowego $\mathrm{nr} 4$.

Adresatem upoważnionym do dokonania ograniczeń praw człowieka jest państwo. Konwencyjne regulacje wyraźnie wskazują na adresata - ustawodawcę, którego można nazwać adresatem pierwotnym. Taka konkluzja wynika wyraźnie z tego fragmentu klauzuli, która mówi, że ingerencja lub ograniczenia muszą być przewidziane przez ustawę (w polskiej wersji językowej EKPC). Sformułowanie „ustawodawca" nie jest w pełni uniwersalne, choć fortunne w systemach prawnych państw kontynentalnych, tym bardziej że zarówno prawa podmiotowe, jak $\mathrm{i}$ ich ograniczenia powinny być dokonywane w ustawie lub innym akcie normatywnym o randze ustawy. Nie należy wykluczać, że w systemach prawa ustawowego ograniczenia będą statuowane również $\mathrm{w}$ aktach podustawowych oraz $\mathrm{w}$ aktach prawa miejscowego. Abstrahując od tego, należy zwrócić uwagę, że tekst autentyczny Konwencji posługuje się sformułowaniem: ,przewidziane przez prawo". Jest ono bardziej szerokie i uniwersalne zarazem, ponieważ obejmuje także orzecznicze stanowienie prawa w państwach systemu common law. Takiemu stanowisku dał wyraz Europejski Trybunał Praw Człowieka (dalej jako: ETPC lub Trybunał) w sprawie Sunday Times ${ }^{29}$, w której stwierdził, że ograniczenia mogą wynikać również z prawa precedensowego. Trudno się było spodziewać innego rozstrzygnięcia Trybunału, skoro w kulturze prawa anglosaskiego wyrok sądowy jest źródłem prawa. Tak czy inaczej, ograniczenie musi być w pierwszej kolejności sformułowane w prawie krajowym, ponieważ jeżeli sprawa trafi do ETPC, to Trybunał w pierwszej kolejności przeprowadza test legalności, sprawdzając, czy ograniczenie było przewidziane prawem. Dopiero w dalszej kolejności pojawiają się adresaci wtórni możliwości dokonywania ograniczenia. Są to przede wszystkim organy stosujące prawo, które wydają akty indywidualno-konkretne, znajdujące podstawę w normach abstrakcyjnych i generalnych. W ich konsekwencji są dokonywane czynności faktyczne organów państwowych, np. stosowanie przy-

${ }^{26}$ „Wolność uzewnętrzniania wyznania lub przekonań może podlegać jedynie takim ograniczeniom, które $[\ldots] "$.

27 „Korzystanie z tych wolności, z racji pociągających za sobą obowiązków i odpowiedzialności, może podlegać takim wymogom formalnym, warunkom, ograniczeniom i sankcjom, jakie są przewidziane $[\ldots] "$.

28 L. Garlicki, [w:] L. Garlicki, Komentarz EKPCz, t. 1, art. 8, Nb 6, Warszawa 2010, s. 483.

29 Sprawa Sunday Times przeciwko Wielkiej Brytanii, wyrok z dnia 26 kwietnia 1979 r., skarga nr 6538/74, a także sprawa McLeod przeciwko Wielkiej Brytanii, wyrok z dnia 23 września 1998 r., skarga nr 24755/94. 
musu bezpośredniego ${ }^{30}$. W taki sposób klauzule limitacyjne kreują ciąg działań prawnych, które znajdują swój początek w postanowieniach EKPC i potencjalnie mogą znaleźć swój finał w Trybunale, a nawet dalej - w prawie krajowym. EKPC upoważnia państwo do dokonania ograniczeń praw człowieka. Właściwe organy państwowe przy spełnieniu pozostałych uwarunkowań (o czym poniżej) mogą ograniczenie sformułować w prawie krajowym, dostosowując je do specyfiki warunków lokalnych. Następnie organy stosujące prawo ograniczą konkretne prawo w stosunku do zindywidualizowanego i skonkretyzowanego podmiotu, a ten jeżeli uzna to za naruszenie jego praw - skieruje sprawę do Trybunału w Strasburgu, który oceni zasadność ingerencji. Jeżeli uzna w wyroku to ograniczenie za niedopuszczalne, to państwo będzie zobligowane usunąć źródło naruszenia, aby wykluczyć podobne naruszenia Konwencji w przyszłości.

Drugim elementem klauzuli limitacyjnej jest szacunkowe wskazanie na konieczność dokonania takiej ingerencji. Ograniczenie praw człowieka jest opatrzone klauzulą konieczności w społeczeństwie demokratycznym, co daje Trybunałowi podstawę do badania zasadności ingerencji dokonanej przez organy krajowe i materializuje się podczas przeprowadzania testu konieczności. Sytu-

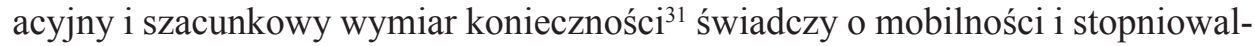
ności tej kategorii, a przez zestawienie jej ze stabilnymi i ugruntowanymi już wartościami demokratycznego społeczeństwa wzmacnia aksjologiczny wymiar dokonania ograniczeń praw człowieka. Nie chodzi bowiem o jakąkolwiek bliżej nieokreśloną konieczność, lecz o konieczność występującą w społeczeństwie demokratycznym. Ingerencja w prawa człowieka ma za zadanie chronić wartości społeczeństwa demokratycznego, które są zagrożone, jeżeli ingerencja ta nie zostanie dokonana. Pomimo tego, że zwrot „konieczny w społeczeństwie demokratycznym" jest uznawany niekiedy za klauzulę generalną o specyficznym charakterze ${ }^{32}$, to jednak bezwzględnie elementem go racjonalizującym jest odwołanie „do zobiektywizowanych wartości »społeczeństwa demokratycznego«, leżących na pograniczu prawno-społecznym"33.

Konstrukcja limitacji kierunkuje organy stanowiące prawo na wartości, w tym również pozaprawne, sformułowane w postaci klauzul generalnych, które można uznać za przesłanki uzasadniające wprowadzanie ograniczeń. Te przesłanki to

30 Szerzej na temat ingerencji w sferę praw człowieka w państwie zob. K. Wojtyczek, Granice ingerencji ustawodawczej w sferę praw człowieka w Konstytucji RP, Kraków 1999, s. 64 i n.

31 L. Leszczyński, Kryterium "konieczności w demokratycznym społeczeństwie” w Europejskiej Konwencji Praw Człowieka - studium teoretycznoprawne, „Europejski Przegląd Sądowy” 2014, nr 1, s. 48.

32 A. Michalska, Klauzule generalne w Europejskiej Konwencji Praw Człowieka, [w:] Teoria prawa, filozofia prawa, współczesne prawo i prawoznawstwo, red. M. Kocoł, W. Lang, Toruń 1998, s. $181-184$.

33 B. Liżewski, op. cit., s. 309. 
np. „interes bezpieczeństwa państwowego”, „integralność terytorialna”, „bezpieczeństwo publiczne”, „względy konieczności zapobieżenia zakłócaniu porządku lub przestępstwu”, „ochrona zdrowia i moralności”, „ochrona dobrego imienia i praw innych osób”, „względy zapobieżenia ujawnienia informacji poufnych”, „zagwarantowanie powagi i bezstronności władzy sądowej”. Ten trzeci element klauzuli limitacyjnej, jako warunek dopuszczalności ingerencji, nazywany jest niekiedy „warunkiem realizacji celu prawowitego" ${ }^{34}$. Twórcy EKPC uznali, że możliwość ograniczenia praw i wolności człowieka tylko ze względu na to, że jest to konieczne w społeczeństwie demokratycznym, stwarzałoby dla ustawodawcy krajowego zbyt duży zakres swobody i uznaniowości. Mogłoby to prowadzić do autonomicznego kreowania celu w każdym państwie Rady Europy, ze względu na który jest dokonywane ograniczenie substancji chronionej prawa. W konsekwencji mogłoby to prowadzić do niekontrolowanego dezintegrowania całego systemu ochrony. Ponadto nawet intuicyjnie, kiedy mówimy o konieczności ograniczenia praw człowieka w społeczeństwie demokratycznym, to automatycznie pojawia się pytanie, dlaczego to ograniczenie jest konieczne. Konwencja na to pytanie odpowiada, formułując w postaci klauzul generalnych wartości, „,których utrwalenie jest istotnym aspektem funkcjonowania państwa, a w jego ramach - społeczeństwa. Dbałość o te wartości może [...] usprawiedliwiać wprowadzenie ograniczeń"35. Można powiedzieć, że ochrona tych wartości staje się dla społeczeństwa demokratycznego priorytetem. Innymi słowy, jeżeli dochodzi do kolizji między prawami wyartykułowanymi w przepisach wyrażających te klauzule a wartościami społeczeństwa demokratycznego, to aksjologiczny ładunek tych wartości przeważa i uzasadnia ograniczenie tych praw. Konstrukcja klauzuli limitacyjnej jest więc jasnym normatywnym przekazem. Prawa człowieka (przynajmniej niektóre) nie są nieograniczone. Istnieją wyższe cele w wymiarze społecznym, które są nadrzędne wobec jednostki i mogą być powodem, dla którego państwo zdecyduje się te prawa jednostce ograniczyć.

\section{POZOSTAŁE KONSTRUKCJE LIMITACJI PRAW I WOLNOŚCI CZŁOWIEKA W EUROPEJSKIEJ KONWENCJI PRAW CZŁOWIEKA}

Poza konstrukcją klauzuli limitacyjnej, wyrażoną w powołanych powyżej przepisach EKPC, klauzule generalne zostały sformułowane także w innych postanowieniach Konwencji. Ich normatywna budowa jest oparta w niektórych przypadkach na nieco odmiennych założeniach, można też wskazać na przepisy zupełnie odmiennie sytuujące instytucje konwencyjnej klauzuli generalnej.

34 R. Mizerski, Test legalności w systemie Europejskiej Konwencji Praw Człowieka, Warszawa 2009, s. 96.

35 B. Liżewski, op. cit., s. 309. 
Wszystkie przepisy EKPC wykorzystujące konstrukcję klauzuli generalnej łączy jednak istotna cecha wspólna, a mianowicie doprecyzowanie prawa chronionego. Słowo „doprecyzowanie” należy w tym miejscu rozumieć szeroko. Może ono być rozumiane trojako. Po pierwsze, jako zezwolenie na modyfikowanie prawa chronionego, prowadzące do jego ograniczenia; po drugie, jako doprecyzowanie, które może skutkować wzmocnieniem prawa, ponieważ EKPC umożliwia państwom podejmowanie autonomicznych decyzji co do określenia zakresu, w jakim prawo to będzie wykonywane i chronione w porządku krajowym - wówczas to od decyzji ustawodawcy będzie zależeć, czy ten zakres ochrony będzie większy czy mniejszy; po trzecie, klauzule generalne mogą służyć zakazowi ingerencji, która mogłaby prowadzić do zróżnicowania ludzi, naruszając substancjalną istotę człowieczeństwa.

Pierwsza grupa przypadków obejmuje konstrukcję klauzuli limitacyjnej oraz klauzulę zawartą $\mathrm{w}$ konstrukcji prawa do rzetelnego procesu sądowego $\mathrm{z}$ art. 6 EKPC i klauzulę $\mathrm{z}$ art. 1 ust. 1 protokołu dodatkowego nr 7 normującego zakaz wydalania cudzoziemców. Klauzule generalne w konstrukcji art. 6 zostały wykorzystane do uzasadnienia wyjątku od generalnej zasady jawności postępowania. W zd. 2 ust. 1 art. 6 czytamy:

Postępowanie przed sądem jest jawne, jednak prasa i publiczność mogą być wyłączone z całości lub części rozprawy sądowej ze względów obyczajowych, z uwagi na porządek publiczny lub bezpieczeństwo państwowe w społeczeństwie demokratycznym, gdy wymaga tego dobro małoletnich lub gdy służy to ochronie życia prywatnego stron albo też w okolicznościach szczególnych, w granicach uznanych przez sąd za bezwzględnie konieczne, kiedy jawność mogłaby przynieść szkodę wymiarowi sprawiedliwości.

Powyższa regulacja kreuje szeroki katalog przyczyn, ze względu na które można wyłączyć jawność postępowania. W katalogu tym możemy wyróżnić dwie grupy przypadków. Pierwsza z nich dotyczy interesu prywatnego, a druga - publicznego. W przypadku interesu prywatnego, związanego ze względami obyczajowymi, dobrem małoletniego i ochroną życia prywatnego, ograniczenie jawności rozprawy ma na celu ochronę szeroko rozumianego interesu prywatnego jednostki. W tym przypadku tworzy się proporcja, w której ograniczenie jednego prawa koreluje z ochroną innego. Od oceny sądu zależy, czy ingerencja w wartości szczególnie cenne dla jednostki na skutek jawnej rozprawy osiągnie taki poziom, który doprowadzi do ich naruszenia. Jeżeli sąd uzna, że taki będzie skutek, wówczas jawność tę ograniczy albo wyłączy. W tym kontekście art. 6 możemy zaliczyć również do drugiej grupy przypadków, w której klauzule generalne służą wzmocnieniu prawa. Ograniczenie jawności rozprawy z uwagi na ochronę interesu publicznego nie opiera się na konfrontowaniu praw, tak jak w przypadku interesu prywatnego jednostek, lecz na ograniczeniu jawności ze względu na wyższość celów sfery publicznej. 
Kolejny przypadek umożliwiający ograniczenie prawa chronionego jest ujęty przepisie art. 1 protokołu dodatkowego $\mathrm{nr}$ 7. Regulacja ta dotyczy zakazu wydalania cudzoziemców ${ }^{36}$, a klauzule „porządku publicznego” i „względów bezpieczeństwa" służą możliwości podjęcia decyzji o wydaleniu cudzoziemca jako wyjątku od generalnej zasady statuującej zakaz dokonywania takiego wydalenia, i to bez skorzystania z podstawowych gwarancji proceduralnych określonych $\mathrm{w}$ lit. a, b, c ust. 1 art. 1. Klauzule ujęte w ust. 2 zostały powiązane ze zwrotami szacunkowymi: ,jeśli jest to konieczne” i „podyktowane względami”. Podjęcie decyzji w przedmiocie wydalenia nakazuje więc ustalenie proporcji między wartościami, ze względu na które wydalenie ma nastąpić, a określeniem skali ingerencji $\mathrm{w}$ te wartości. Rozwiązanie przyjęte w tym przepisie nie jest analogiczne do tego przyjętego w przepisach z formułą klauzuli limitacyjnej. Regulacje te przewidują określone prawa człowieka, a klauzula umożliwia ich ograniczenie. Gdyby analizowany przepis art. 1 przewidywał analogiczne rozwiązanie, formułowałby prawo cudzoziemca do tego, żeby nie być wydalonym. W takiej sytuacji wydalenie można by było traktować jako ograniczenie tego prawa. Tak jednak nie jest, ponieważ przepis art. $1 \mathrm{w}$ ust. 1 stanowi wyłącznie o zakazie wydalenia. Skutek tego rozwiązania jest jednak podobny, ponieważ wydalenie przekreśla faktyczną możliwość pobytu cudzoziemca w państwie, które go gości.

Druga grupa sprowadza się zasadniczo do regulacji art. 1 protokołu dodatkowego $\mathrm{nr} 1$, gwarantującego prawo własności ${ }^{37}$. Można spotkać się z poglądem, że zd. 3 tego przepisu ${ }^{38}$ jest regulacją najbardziej zbliżoną do konstrukcji klauzuli limitacyjnej ${ }^{39}$. Wydaje się oczywiście uzasadnione doszukiwanie się

36 Art. 1: „Gwarancje proceduralne dotyczące wydalania cudzoziemców: 1. Cudzoziemiec legalnie przebywający na terytorium jakiegokolwiek państwa nie może być zeń wydalony, chyba że w wyniku decyzji podjętej zgodnie z ustawą, i powinien mieć możliwość: a) przedstawienia powodów przeciwko wydaleniu, b) wniesienia środków odwoławczych, oraz c) bycia reprezentowanym dla tych celów przed właściwym organem albo osobą lub osobami wyznaczonymi przez ten organ. 2. Cudzoziemiec może być wydalony, bez uprzedniego skorzystania ze swoich praw wymienionych $\mathrm{w}$ ustępie 1a, b, c niniejszego artykułu, jeśli jest to konieczne $\mathrm{z}$ uwagi na porządek publiczny lub uzasadnione względami bezpieczeństwa narodowego".

37 EKPC w regulacji tego przepisu posługuje się pojęciami „własność” i „mienie”, nadając temu ostatniemu za pośrednictwem orzecznictwa ETPC autonomiczne i jednocześnie szerokie znaczenie. Zgodnie z nim mienie to nie tylko własność, ale także inne prawa i korzyści majątkowe obejmujące wierzytelności, roszczenia, środki pomocy, do których ma się uprawnienie, własność intelektualną, prawa autorskie i patenty. Ponadto, zgodnie z orzeczeniem Van Marle i inni przeciwko Holandii z dnia 23 października 1986 r. (skargi nr 8543/79, nr 8674/79, nr 8675/79, nr 8685/79), w pewnych okolicznościach za mienie uznaje się również klientów kancelarii, np. adwokackiej.

38 Powyższe postanowienia nie będą jednak w żaden sposób naruszać prawa państwa do stosowania takich ustaw, jakie uzna za konieczne do uregulowania sposobu korzystania z własności zgodnie $\mathrm{z}$ interesem powszechnym lub w celu zabezpieczenia uiszczania podatków bądź innych należności lub kar pieniężnych.

39 R. Mizerski, op. cit., s. 101. 
pewnych podobieństw, ale skutki wynikające $z$ tej regulacji są znacznie dalej idące. $\mathrm{Z}$ treści art. 1 można wyinterpretować trzy normy. Pierwsza z nich ustala regułę ogólną korzystania z mienia, druga przewiduje możliwość pozbawienia własności, a trzecia odnosi się do sposobu korzystania z własności. Dwie spośród tych norm (druga i trzecia) wykorzystują formułę klauzul generalnych. Pozbawienie własności obok podstawy ustawowej powinno być usprawiedliwione interesem publicznym oraz ogólnymi zasadami prawa międzynarodowego. $Z$ kolei interes powszechny jest podstawą do formułowania przepisów formułujących reguły korzystania z własności. Norma ta eksponuje zabezpieczenie uiszczania podatków, innych należności lub kar pieniężnych jako cele, które państwo może prawnie zabezpieczyć, a które bez wątpienia stanowią istotne obciążenia dla właściciela. Pierwsze wrażenie komentatora tej regulacji może prowadzić do konkluzji, że klauzule generalne interesu publicznego i powszechnego służą przede wszystkim do ograniczania prawa własności. Jest to jednak tylko pierwsze wrażenie. Głębsza refleksja prowadzi do odmiennych wniosków. Oczywiście nie ma żadnych wątpliwości, że norma pozwalająca na pozbawienie własności substancjalnie jest nie tylko ograniczająca, ale wręcz wyłącza to prawo. Niemniej klauzula interesu publicznego nie jest konstrukcją, która ma wzmocnić prawo pozbawienia własności, tylko jest de facto przewidziana jako swoiste „utrudnienie” w realizacji tego pozbawienia. Szerokie rozumienie interesu publicznego jako wszelkich racji politycznych, społecznych i gospodarczych w gruncie rzeczy ma ograniczać nie prawo własności, lecz możliwość pozbawienia tego prawa tylko do sytuacji, które na szali wartości są identyfikowane ze wspólnotą ludzką, społeczeństwem i okazują się donioślejsze niż prawo własności przysługujące jednostce. Trybunał co do zasady uznaje, że „pozbawienie własności tylko z tego powodu, aby przysporzyć korzyści jednostce prywatnej, nie następuje w interesie publicznym"40, chociaż nie wyklucza wyjątków wiązania interesu publicznego z jednostką ${ }^{41}$.

Aspekt uregulowania sposobu korzystania $\mathrm{z}$ własności nie powinien być rozpatrywany wyłącznie w kontekście obciążeń, jakie państwo narzuci na właściciela. Sposób korzystania z własności to przede wszystkim stworzenie prawnych ram, w oparciu o które właściciel będzie korzystał ze swojego prawa w poczuciu pewności prawnej i bezpieczeństwa, ponosząc niezbędne koszty jego wykonywania. Klauzula interesu powszechnego ma być podstawą do kształtowania przez państwo tych reguł. Wydaje się, że należy skłaniać się ku poglądowi, że interes powszechny nie ma wymiaru uniwersalnego, a więc w każdym państwie może być inny. Takie rozumienie uzasadniałoby „prawie nieograni-

40 A. Wróbel, [w:] L. Garlicki, Komentarz EKPCz, t. 2, art. 1 Protokołu nr 1, Nb 50, Warszawa 2011, s. 505.

${ }^{41}$ Ibidem. 
czoną władzę"42 każdego państwa co do określenia prawnych reguł korzystania z własności. Należy przy tym zauważyć, że każde państwo, posiadając autonomię regulacyjną, może, będąc zdeterminowane interesem powszechnym, określić reguły tego korzystania. W jednych państwach obciążenia właściciela będą większe i wtedy będzie można mówić o swoistym ograniczaniu prawa własności, w innych zaś właściciel będzie wykonywał swoje prawo w sposób nieskrępowany. Powstanie więc skala oparta o kryterium „ciężaru obciążającego właściciela" co do sposobu korzystania z własności. W tym sensie regulacja art. 1, wiążąca autonomię ustawodawcy co do sposobu uregulowania własności z klauzulą interesu powszechnego, może być źródłem rozwiązań ułatwiających lub utrudniających korzystanie z tego prawa.

Trzecią grupę ilustruje przepis art. 14 zakazujący dyskryminacji ${ }^{43}$. Zakaz ten - jak pisze A. Wróbel - „stanowi w świecie cywilizowanym powszechnie uznany element statusu jednostki, wynikający z bardziej ogólnego przeświadczenia, że status ten wyznaczają zasady równości i wolności" ${ }^{44}$. Klauzule generalne zostały wkomponowane w otwarty katalog kryteriów (podstaw dyskryminacji), które mogą służyć różnicowaniu ludzi, doprowadzając do ich dyskryminacji. Odwołują się one - obok płci, rasy, koloru skóry i języka (pojęcia te są semantycznie dość jednoznaczne) - do pochodzenia narodowego lub społecznego, przynależności do mniejszości narodowej, religii, przekonań politycznych i innych (jak można wnioskować - przekonań). Otwarty katalog miał na celu pozostawienie miejsca na ewentualne nowe podstawy dyskryminacyjne, które w perspektywie rozwoju społeczeństw mogły się pojawić. Czas pokazał, że to założenie okazało się słuszne, a niektóre nowe kryteria również odwołują się do wartości pozaprawnych. Tak należy traktować owe „inne przyczyny”, a wśród nich np. bycie osobą odmawiającą służby wojskowej ze względów sumienia, status zawodowy czy orientację seksualną ${ }^{45}$. Warto nadmienić, że zakaz dyskryminacji jako naturalna konsekwencja zasady równości wobec prawa w ujęciu konwencyjnym w sposób wyraźny ma służyć zakazowi naruszania praw zawartych w EKPC w wyniku działań dyskryminacyjnych. Zakaz ten zresztą został rozszerzony na wszystkie prawa podmiotowe za sprawą ust. 1 art. 1 protokołu dodatkowego $\mathrm{nr} 12^{46}$.

42 P. van Dijk, F. van Hoof, A. van Rijn, L. Zwaak, Theory and Practise of the European Convention on Human Rights, The Hague 1997, s. 887.

43 Art. 14 EKPC stanowi: „Korzystanie z praw i wolności wymienionych w niniejszej Konwencji powinno być zapewnione bez dyskryminacji wynikającej z takich powodów, jak płeć, rasa, kolor skóry, język, religia, przekonania polityczne i inne, pochodzenie narodowe lub społeczne, przynależność do mniejszości narodowej, majątek, urodzenie bądź z jakichkolwiek innych przyczyn”.

${ }_{44}$ A. Wróbel, [w:] L. Garlicki, Komentarz EKPCz, t. 1, art. 14, Nb 1, s. 755.

45 M.A. Nowicki, Wokót Konwencji Europejskiej. Komentarz do Europejskiej Konwencji Praw Człowieka, wyd. 6, Warszawa 2013, s. 958.

46 Art. 1 ust. 1 protokołu dodatkowego nr 12 stanowi: „Korzystanie z każdego uprawnienia ustanowionego przez prawo będzie zapewnione bez dyskryminacji z jakiegokolwiek powodu, takie- 


\section{UWAGI KOŃCOWE}

W podsumowaniu problematyki odesłań pozaprawnych w Europejskiej Konwencji Praw Człowieka w sposób naturalny pojawia się perspektywa porządku prawa krajowego. Po pierwsze, dlatego że konstrukcja klauzul generalnych, wprowadzona w XIX w. dla zapewnienia elastyczności stosowania prawa w państwie, dopiero z czasem przeniknęła do prawa międzynarodowego. Zyskała w nim jednak swoje autonomiczne znaczenie. Niemniej kontekst porównania konstrukcji klauzul w obu systemach wydaje się naturalny, tym bardziej z perspektywy teoretycznoprawnej. Po drugie, system Konwencji został powołany w celu wyznaczania standardów ochrony praw człowieka oraz korygowania prawa i praktyki jego stosowania w każdym z państw Rady Europy. Konwencyjne klauzule generalne również wpisują się w proces kształtowania tych relacji.

Narzucają się przy tym następujące konkluzje. Konstrukcja klauzul generalnych w EKPC i protokołach dodatkowych służy przede wszystkim umożliwieniu ograniczania praw człowieka. Realizowanie tego zadania za pośrednictwem klauzul limitacyjnych dotyczy praw ludzi, które są powszechne i substancjalnie związane z każdym człowiekiem. Prywatność, rodzina, mieszkanie, korespondencja, swoboda wypowiedzi, religia, a także możliwość manifestowania swoich poglądów i członkostwo w różnych organizacjach na co dzień wypełniają życie człowieka. Stąd bierze się istotność konstrukcji klauzul limitacyjnych. W artykule zostało pokazane, że konstrukcja klauzul ma wymiar szerszy i jest wykorzystywana również dla formułowania sposobu korzystania z innych praw człowieka. Prawo własności, do sądu, zakaz dyskryminacji i zakaz wydalania cudzoziemców także, aczkolwiek w inny sposób, odwołują się do konstrukcji klauzul, czerpiąc z odesłań pozaprawnych podstawy do dookreślania sposobu korzystania z tych praw, niekiedy nawet doprowadzając do ich wzmocnienia.

W większości przypadków adresatami przepisów opatrzonych klauzulami generalnymi są dwie kategorie podmiotów. Pierwsza z nich to krajowy ustawodawca. Ten adresat pierwotny, czerpiąc z upoważnienia EKPC, kształtuje krajowe podstawy prawne, dostosowując ograniczenia bądź doprecyzowanie praw człowieka do specyfiki warunków lokalnych, wykorzystując w tym celu pozaprawne wartości, na które kierunkuje go Konwencja. Ustanowione w tej formule prawo krajowe (w założeniu precyzyjne i adekwatne do specyfiki społecznego otoczenia prawa), włącznie z postanowieniami EKPC, jest kierowane do adresata wtórnego - organów stosujących prawo. Organy te, w oparciu o podstawy prawne i przy wykorzystaniu swojego zakresu władzy dyskrecjonalnej, podejmują indywidualno-konkretne decyzje stosowania prawa wobec osób fizycznych i innych podmio-

go jak płeć, rasa, kolor skóry, język, religia, przekonania polityczne lub inne, pochodzenie narodowe lub społeczne, przynależność do mniejszości narodowej, majątek, urodzenie lub z jakichkolwiek innych przyczyn". 
tów prawa. Zarówno krajowe działania prawodawcze, jak i decyzje stosowania prawa mogą stać się przedmiotem kontroli ETPC. Skarga indywidualna może (jeżeli zostanie uznana za dopuszczalną) zainicjować proces kontroli, w którym strasburski Trybunał oceni, czy krajowe organy nie przekroczyły marginesu uznania i nie naruszyły praw człowieka.

Na końcu należy jeszcze wspomnieć, że zawarte w konwencyjnych przepisach klauzule generalne są najczęściej powiązane ze zwrotami nakazującymi szacowanie w obrębie tymi wartościami wyznaczonymi. Nakaz szacowania, czyli tzw. konieczność w społeczeństwie demokratycznym albo „konieczność”, jest wprowadzany zawsze wówczas, gdy regulacja EKPC dopuszcza wprowadzenie ograniczenia praw człowieka. W takiej sytuacji ograniczenie ma być nie tylko legalne, ale i konieczne ze względu na ochronę między innymi wartości, których źródło tkwi poza prawem. Konkludując, należy stwierdzić, że konstrukcja klauzul generalnych w EKPC ma na celu umożliwienie i zapewnienie elastyczności w tworzeniu i stosowaniu prawa praw człowieka na poziomie krajowym, a wprowadzane ograniczenia praw człowieka albo określenie korzystania z praw należnych jednostce musi być dostosowane do specyfiki warunków lokalnych.

\section{BIBLIOGRAFIA}

Czapliński W., Wyrozumska A., Prawo międzynarodowe publiczne. Zagadnienia systemowe, Warszawa 1999.

Dijk P. van, Hoof F. van, Rijn A. van, Zwaak L., Theory and Practise of the European Convention on Human Rights, The Hague 1997.

Encyklopedia zagadnień międzynarodowych, red. E. Cała-Wacinkiewicz, R. Podgórzańska, D. Wacinkiewicz, Warszawa 2011.

Garlicki L., [w:] L. Garlicki, Komentarz EKPCz, t. 1, art. 8, Nb 6, Warszawa 2010.

Gilas J., Prawo międzynarodowe, wyd. 2 popr. i zm., Toruń 1999.

Góralczyk W., Prawo międzynarodowe publiczne w zarysie, wyd. 8 zm. i popr. przez S. Sawickiego, Warszawa 2002.

Kordela M., Zasady prawa. Studium teoretycznoprawne, Poznań 2012.

Lammers J.G., General Principles of Law Recognized by Civilized Nations, [w:] Essays on the Development of the International Legal Order. In Memory of Haro F. van Panhuys, eds. F. Kalsharen, P.J. Kuyper, J.G. Lammers, Sithoff 1980.

Latos B., Klauzula derogacyjna i limitacyjna w Europejskiej Konwencji Praw Człowieka i Podstawowych Wolności, Warszawa 2008.

Leszczyński L., Klauzule generalne w stosowaniu prawa, Lublin 1986.

Leszczyński L., Kryterium , konieczności w demokratycznym społeczeństwie” w Europejskiej Konwencji Praw Człowieka - studium teoretycznoprawne, „Europejski Przegląd Sądowy” 2014, nr 1.

Leszczyński L., Maroń G., Pojęcie i treść zasad prawa oraz generalnych klauzul odsyłajacych. Uwagi porównawcze, „Annales UMCS. Sectio G” 2013, Vol. 40, nr 1.

Liżewski B., Operacjonalizacja ochrony praw człowieka w porzadku Europejskiej Konwencji Praw Człowieka (studium teoretycznoprawne), Lublin 2015.

Łazowski A., Zawidzka A., Prawo międzynarodowe publiczne, wyd. 2, Warszawa 2003.

Maroń G., Zasady prawa. Pojmowanie i typologie a rola w wyktadni prawa i orzecznictwie konstytucyjnym, Poznań 2011. 
Michalska A., Klauzule generalne w Europejskiej Konwencji Praw Człowieka, [w:] Teoria prawa, filozofia prawa, wspótczesne prawo i prawoznawstwo, red. M. Kocoł, W. Lang, Torun 1998.

Mizerski R., Test legalności w systemie Europejskiej Konwencji Praw Człowieka, Warszawa 2009.

Nowicki M.A., Wokół Konwencji Europejskiej. Komentarz do Europejskiej Konwencji Praw Człowieka, wyd. 6, Warszawa 2013.

Połatyńska J., Pozycja słuszności w prawie międzynarodowym, [w:] Prawo międzynarodowe wobec wyzwań wspótczesnego świata, red. E. Dynia, Rzeszów 2009.

Shaw M.N., Prawo międzynarodowe, przeł. J.J. Gojło [et al.], Warszawa 2011.

Tkacz S., O zintegrowanej koncepcji zasad prawa w polskim prawoznawstwie (od dogmatyki do teorii), Toruń 2014.

Wentkowska A., Zasady wspólne dla państw członkowskich - u źródet niepisanego ius commune Europaeum, [w:] Zasady ogólne prawa wspólnotowego, red. C. Mik, Torun 2007.

Wojtyczek K., Granice ingerencji ustawodawczej w sfere praw człowieka w Konstytucji RP, Kraków 1999.

Wronkowska S., Zieliński M., Ziembiński Z., Zasady prawa. Zagadnienia podstawowe, Warszawa 1974.

Wróbel A., [w:] L. Garlicki, Komentarz EKPCZ, t. 1, art. 14, Nb 1, Warszawa 2010.

Wróbel A., [w:] L. Garlicki, Komentarz EKPCz, t. 2, art. 1 Protokołu nr 1, Nb 50, Warszawa 2011.

\section{SUMMARY}

The paper deals with the extra-legal references of the European Convention of Human Rights, differing form the way in that such axiology is the state or general international law. The latter cumulates both intra and extra legal values in the category of the general principles of law and these constructs, together with the general clauses enter the international human rights law. Paper accepts the concept of the clauses not restricting them to the category of the limitation clauses. The various regulations of the Convention had been analyzed in that light both from the point of the international and state law perspectives, since use of the clauses by the state agencies are controlled by the European Court of Human Rights.

Keywords: axiology; human rights; general clauses; limitation clauses

\section{STRESZCZENIE}

Niniejszy artykuł stanowi omówienie teoretycznych aspektów problematyki odesłań pozaprawnych w Europejskiej Konwencji Praw Człowieka. Tło i podbudowę prezentowanego zagadnienia stanowiły krótkie rozważania o formach wyrażania aksjologii prawnej i pozaprawnej w systemach prawa krajowego i w systemie prawa międzynarodowego. W systemie prawa międzynarodowego rzadziej sięga się do konstrukcji klauzul generalnych jako typowych nośników wartości pozaprawnych, co nie oznacza, że prawo międzynarodowe całkowicie zrezygnowało z tej konstrukcji. Klauzule te znalazły swoje miejsce między innymi w międzynarodowym prawie praw człowieka i w będącej podstawą rozważań EKPC. Artykuł prezentuje normatywne ujęcie klauzul generalnych w Konwencji, skupiając się przede wszystkim na konstrukcji klauzul limitacyjnych. Konstrukcja ta, zasadniczo wykorzystywana do ograniczania praw człowieka, ma jednocześnie wymiar międzysystemowy, ponieważ będąc integralnym elementem EKPC, jest kierowana w pierwszej kolejności do krajowego ustawodawcy, który dokonuje ograniczeń praw człowieka w aktach normatywnych prawa krajowego. Akty te są następnie podstawą decyzji stosowania prawa ograniczających prawa człowieka, a te następczo mogą podlegać kontroli Europejskiego Trybunału Praw Człowieka.

Słowa kluczowe: aksjologia; prawa człowieka; klauzule generalne; klauzule limitacyjne 